DOI: $10.21802 /$ artm.2019.4.12.36.

УДК 612.1-06:616.281:616.15

\title{
ВПЛИВ ВЕСТИБУЛЯРНОГО НАВАНТАЖЕННЯ НА СИСТЕМУ КРОВООБІГУ ЗА РІЗНИХ ТИПІВ ПОГОДИ
}

\author{
С.Н. Вадзюк, Р.М. Шмата, Л.Б. Лозіна
}

Тернопільський національний медичний університет ім. І.Я Горбачевського МОЗ України, кафедра фізіології з основами біоетики та біобезпеки, м. Тернопіль, Україна, ORCID ID: 0000-0001-9105-8205, e-mail:vadzyuk@tdmu.edu.ua, ORCID ID:0000-0003-0773-4717,e-mail:roman@tdmu.edu.ua, ORCID ID: 0000-0001-6129-0097,e-mail: lozyna@tdmu.edu.ua

Резюме. Дослідження функціональної активності вестибулярного аналізатора мають важливе значення, оскільки він не тільки контролює положення тіла в просторі, забезпечує його рівновагу, але й приймає участь у регуляції функціонування інших систем організму.

Мета дослідження. Оцінити вплив вестибулярного навантаження на функціональний стан системи кровообігу за різних типів погоди для визначення у майбутньому показів до метео-профілактики.

Матеріали і методи. Визначали величину артеріального тиску та частоту серцевих скорочень до та після вестибулярного навантаження, на основі яких оцінювали вестибулярну стійкість при I та III типах погоди.

Результати дослідження та їх обговорення. При I типі погоди в осіб із відмінною вестибулярною стійкістю ми спостерігали незначне підвищення показників систолічного і діастолічного АТ та ЧСС, що при оцінці вестибулярної стійкості за методикою Н.Н. Лозанова і І.П. Байченка дорівнювало в середньому 4,8 бали. При III типі погоди в осіб, які не відмічали проявів вестибулярної дисфункції, ми спостерігали тенденцію до зниження вестибулярної стійкості. В осіб із достатньою вестибулярною стійкістю та недостатньою вестибулярною стійкістю, при I типі погоди середня вестибулярна стійкість дорівнювала 2,8 бали, що супроводжувалось більшою зміною величини АТ та ЧСС. При ІІІ типі погоди кількість осіб із недостатньою вестибулярною стійкістю значно збільшилась, а саме: у 57 \% осіб, у яких при першому типі погоди показник вестибулярної стійкості дорівнював рівню «достатня стійкість», при III типі він знизився до рівня «недостатня вестибулярна стійкість».

Висновки. Оцінюючи відповіді системи кровообігу на вестибулярне навантаження при I і III типах погоди, встановили зниження вестибулярної стійкості при III типі погоди порівняно з I.

Ключові слова: вестибулярна стійкість, тип погоди, артеріальний тиск, частота серцевих скорочень.

Вступ. Дослідження функціональної активності вестибулярного аналізатора мають важливе значення, оскільки він не тільки контролює положення тіла в просторі, забезпечує його рівновагу, але й приймає участь у регуляції функціонування інших систем організму $[1,2]$. Водночас відомо, що погода, впливаючи на людину, викликає різноманітні реакції організму через інтегральний характер і багатофакторність іiі дії. У науковій літературі представлені дані про реакції на дію погодних факторів з боку різних систем організму [3].

Обгрунтування дослідження. У комплексному вивченні метеореактивності здорового організму найменш досліджено вестибулярний аналізатор, хоча він $є$ дуже чутливим до гіпоксії - основного чинника у визначенні типу погоди [4]. Крім цього, він тісно взаємозв'язаний з серцево-судинною системою $[5]$.

Метою дослідження було оцінити вплив вестибулярного навантаження на функціональний стан системи кровообігу за різних типів погоди для визначення у майбутньому показів до метео-профілактики.

Матеріали та методи. В обстеженні взяли участь 174 студенти (114 дівчат і 60 хлопців), в яких ми оцінили вестибулярну стійкість (ВС) за методикою Н.Н. Лозанова та І.П. Байченка, здійснюючи обертальні проби на кріслі Барані при I і III типах погоди. Величину артеріального тиску (САТ - систолічного, ДАТ - діастолічного) і частоту серцевих скорочень (ЧСС) визначали до та після вестибулярного навантаження. Вестибулярну стійкість оцінювали в балах за такою шкалою: вище 4,5 балів - висока стійкість вестибулярного аналізатора, від 3,0 до 4,5 достатня, нижче 3,0 балів - недостатня [6].

Параметри, отримані під час об'єктивного обстеження серцево-судинної системи, було використано для розрахунку пульсового тиску (ПТ), який відображає кінетичну енергію кровотоку; загального судинного периферичного опору (ЗСПО); рівня обмінно-енергетичних процесів у міокарді, за індексом Робінсона (IP); зміни рівня напруги механізмів регуляції діяльності серцево-судинної системи (ТСК) [7].

Статистичне опрацювання даних проводили методом непараметричної статистики, встановлюючи Т-критерій Вілкоксона та U-критерій Манна-Уітні [8].

Результати дослідження. За результатами обертальної проби, проведеної при I типі погоди, ми розділили обстежуваних на 3 групи, залежно від ВС: 1 група - висока стійкість - 60 осіб, 2 група - достатня стійкість - 47 осіб, 3 група - недостатня стійкість 67 осіб (табл.1). 
Визначення ВС при III типі погоди показало (див. табл.1) зменшення кількості осіб, в яких ми відмічали «достатній» рівень ВС, збільшилась кількість осіб із рівнем «недостатня ВС».

Середні показники балів ВС за методикою Н.Н. Лозанова і І.П. Байченка при I типі погоди ста- новили (табл. 1): у першої групи - 4,8, у другої - 3,5, у третьої - 2,3; при III типі: у першої групи - 4,5, у другої - 3,05, у третьої-2,0.

Середні значення балів(M, m) та зміна кількості осіб відносно вестибулярної стійкості при I та погоди за методикою Н.Н. Лозанова і І.П. Байченка

\begin{tabular}{|c|c|c|c|c|c|}
\hline \multicolumn{2}{|c|}{ Висока стійкість } & \multicolumn{2}{|c|}{ Достатня стійкість } & \multicolumn{2}{c|}{ Недостатня стійкість } \\
\hline 1 тип погоди & 3 тип погоди & 1 тип погоди & 3 тип погоди & 1 тип погоди & 3 тип погоди \\
\hline $\mathrm{n}-60$ & $\mathrm{n}-60$ & $\mathrm{n}-47$ & $\mathrm{n}-20$ & $\mathrm{n}-67$ & $\mathrm{n}-94$ \\
\hline $4,8 \pm 0,2$ & $4,5 \pm 0,05$ & $3,5 \pm 0,3$ & $3,05 \pm 0,15$ & $2,3 \pm 0,2$ & $2,0 \pm 0,3$ \\
\hline
\end{tabular}

Зміни САТ, ДАТ та ЧСС після вестибулярного навантаження при різних типах погоди

\begin{tabular}{|c|c|c|c|c|c|c|}
\hline \multicolumn{3}{|c|}{ Висока - n-60 } & \multicolumn{2}{|c|}{ Достатня - n-47 } & \multicolumn{2}{|c|}{ Недостатня - n-67 } \\
\hline \multicolumn{7}{|c|}{ САТ(M, m), мм.рт.ст } \\
\hline До & $118,3 \pm 4,6$ & $119,9 \pm 5,0 *$ & $118,6 \pm 5,9$ & $114,8 \pm 8,0^{* *}$, & $114,2 \pm 9,2 \bullet \bullet, \bullet ৬$ & $112,8 \pm 9,0 \diamond$ \\
\hline Після & $119,1 \pm 5,2$ & $122,1 \pm 5,1 * * *$ & $125,8 \pm 10,0$ & $132,4 \pm 7,2 * * *$ & $134,5 \pm 8,1 \bullet$ & $\begin{array}{l}136,2 \pm 8,7 \\
\bullet, \bullet \bullet\end{array}$ \\
\hline $\mathrm{p}$ & $<0,05$ & $<0,01$ & $<0,01$ & $<0,01$ & $<0,01$ & $<0,01$ \\
\hline \multicolumn{7}{|c|}{ ДАТ(М, m), мм.рт.ст } \\
\hline До & $78,3 \pm 3,7$ & $77,6 \pm 5,5$ & $79,0 \pm 5,7$ & $73,5 \pm 9,0 * *$ & $70,1 \pm 8,6$ & $73,2 \pm 9,5 \bullet$ \\
\hline Після & $77,8 \pm 3,8$ & $76,3 \pm 4,9$ & $75,7 \pm 7,7$ & $77,2 \pm 8,8$ & $77,3 \pm 7,8$ & $77,2 \pm 6,8$ \\
\hline $\mathrm{p}$ & $>0,05$ & $<0,01$ & $<0,05$ & $<0,05$ & $<0,01$ & $<0,01$ \\
\hline \multicolumn{7}{|c|}{ ЧСС $(\mathrm{M}, \mathrm{m})$, уд/10c } \\
\hline До & $11,9 \pm 1,6$ & $11,7 \pm 1,6$ & $11,2 \pm 1,3 \downarrow$ & $12,4 \pm 1,5^{* *}$, & $12,9 \pm 1,5 \bullet \downarrow, \diamond ৬$ & $12,5 \pm 1,4 \bullet$ \\
\hline Після & $12,4 \pm 1,8$ & $12,4 \pm 2,02$ & $13,5 \pm 1,7$ & $15,6 \pm 2,5 * * *$, & $16,3 \pm 2,2 \triangleleft \downarrow, \diamond ৬$ & $16,2 \pm 2,4 \bullet$ \\
\hline $\mathrm{p}$ & $<0,01$ & $<0,01$ & $<0,01$ & $<0,01$ & $<0,01$ & $<0,01$ \\
\hline
\end{tabular}

Примітка: $\mathrm{p}<0,05^{*}-$ вірогідність різниці показників у стані спокою при I і III типах погоди; $<_{0,01}^{* *}$ вірогідність різниці показників у стані спокою при I і III типах погоди; $p<0,01 * * *$ - вірогідність різниці показників після вестибулярного навантаження при I і III типах погоди; p $<0,05 * * * *$ - вірогідність різниці показників після вестибулярного навантаження при I і III типах погоди; $\vee p<0,05$ - вірогідність різниці показників між особами 3 відмінною та достатньою ВС, $\bullet$ р $<0,05$ - вірогідність різниці показників між особами 3 відмінною та недостатньою ВС, «р<0,05 - вірогідність різниці показників між особами з достатньою та недостатньою ВС.

У стані спокою у групи з високою ВС показник САТ при III типі погоди був вищим $(\mathrm{p}<0,05)$, ніж при I типі; ДАТ - не відрізнявся; ЧСС - не відрізнявся (табл. 2). Підвищення САТ у групи з високою ВС до та після вестибулярного навантаження було достовірне при I ( $<<0,05)$ і III $(\mathrm{p}<0,01)$ типах погоди. Досліджуючи вплив погоди на ВС, ми порівняли цей покаЗник до та після обертальної проби і встановили, що при III типі погоди після обертальної проби він був достовірно вищим ( $<<0,01)$, ніж при I типі.

ДАТ до та після вестибулярного навантаження не відрізнявся ні при I, ні при III типах погоди; також різниці між показником ДАТ окремо у стані спокою та після навантаження, отриманого при I типі погоди та III типі, ми не виявили. Підвищення ЧСС у групі з високою ВС після вестибулярного навантаження ми спостерігали при I i III типах погоди $(\mathrm{p}<0,01)$, однак, порівнюючи цей показник після вес- тибулярного навантаження при I і III типах погоди, різниці ми не виявили.

До вестибулярного навантаження у групі 3 достатньою ВС показники відрізнялись наступним чином: САТ і ДАТ був вищим при I типі, ніж при III типі погоди $(\mathrm{p}<0,01)$; ЧСС - була вищою при III типі погоди, ніж при I типі $(\mathrm{p}<0,01)$ (табл. 2). Підвищення САТ у групі з достатньою ВС після вестибулярного навантаження було достовірне при I $(\mathrm{p}<0,01)$ i III $(\mathrm{p}<0,01)$ типах погоди. Порівняння цього показника після обертальної проби показало, що при III типі погоди він був достовірно вищим ( $<0,01)$, ніж при I типі. ДАТ після вестибулярного навантаження при I типі погоди знизився ( $<<0,05)$, а при III - підвищився $(p<0,01)$. Порівнюючи цей показник після навантаження, при I та III типах погоди різниці ми не знайшли. Підвищення ЧСС у групі з достатньою ВС після вестибулярного навантаження ми спостерігали при I i 
III типах погоди $(\mathrm{p}<0,01)$, також, порівнюючи цей показник після вестибулярного навантаження при I i III типах погоди, ми визначили, що при I типі погоди він є вищим, ніж при III ( $<<0,01)$.

Порівнюючи показники САТ, ДАТ та ЧСС до вестибулярного навантаження у групі з недостатньою ВC при I і III типах погоди, різниці ми не знайшли. Після обертальної проби у них досліджувані показники як при I, так і при III типі погоди підвищились $(\mathrm{p}<0,01)$, порівняно із отриманими даними до навантаження. Порівнюючи показники після вестибулярного навантаження залежно від типу погоди у групі 3 недостатньою ВС, різниці між ними ми не знайшли (табл. 2).

Порівнюючи показники САТ, ми встановили, що у стані спокою при III типі погоди у групі із достатньою ВС він був нижчим, ніж у групі з високою $\mathrm{BC}(\mathrm{p}<0,05), \mathrm{i}$ був вищим після вестибулярного навантаження, як при I та III типі погоди, ніж у групі 3 високою ВС $(\mathrm{p}<0,05)$. При порівнянні САТ у групах 3 високою ВC і з недостатньою ВС, ми знайшли відмінності. У стані спокою САТ був нижчим у групі 3 недостатньою ВC, ніж у групі з високою ВC при I і III типі погоди $(\mathrm{p}<0,05)$; після вестибулярного навантаження САТ був вищий у групі з недостатньою ВС при I і III типах погоди, порівняно з результатами у групі з високою ВС (p<0,05). При порівнянні САТ у групах із достатньою та недостатньою ВС ми спостерігали нижчий САТ у стані спокою у групі з недостатньою ВС, ніж у групі із достатньою ВС при I типі погоди та вищий САТ після обертальної проби у групі з недостатньою ВС при I i III типах погоди, порівняно з групою із достатньою ВС $(\mathrm{p}<0,05)$ (табл. 2).

Показник ДАТ у стані спокою при III типі погоди у групі з високою ВС був вищим, ніж у групі iз 3 достатньою $\mathrm{BC}(\mathrm{p}<0,05)$. ДАТ до обертальної проби у групі з високою ВС був вищим при I та III типі погоди, ніж у групі з недостатньою ВС ( $<0,05)$.

У стані спокою відмінність ЧСС ми знайшли у групах з високою ВС та достатньою ВС при I та III типі погоди, а саме при I типі у групі з достатньою ВC він був нижчим $(\mathrm{p}<0,05)$, а при III типі був вищим $(\mathrm{p}<0,05)$, ніж у групі з високою ВС. Також є відмінність між ЧСС після обертальної проби. У групі із достатньою ВС показник ЧСС був вищим при I і III типах погоди, ніж у групі з високою ВС.

Порівнюючи ЧСС між групою з високою ВС та групою з недостатньою ВС, ми спостерігали вищі показники у групі 3 недостатньою ВС, ніж у групі 3 високою ВС, у стані спокою та після навантаження як при I, так і при III типах погоди $(\mathrm{p}<0,05)$.

При порівнянні ЧСС між групами 3 достатньою ВС та недостатньою ВС встановили, що вищі показники були при I типі погоди у групі з недостатньою ВС, як у стані спокою, так і після навантаження $(\mathrm{p}<0,05)$ (табл. 2).

У стані спокою у групи з високою ВС показник ПТ при III типі погоди був вищим $(\mathrm{p}<0,05)$, ніж при I типі. Після вестибулярного навантаження показник ПТ достовірно підвищився, порівняно зі станом спокою, як при I $(\mathrm{p}<0,01)$, так і III $(\mathrm{p}<0,01)$ типах погоди (рис. 1).

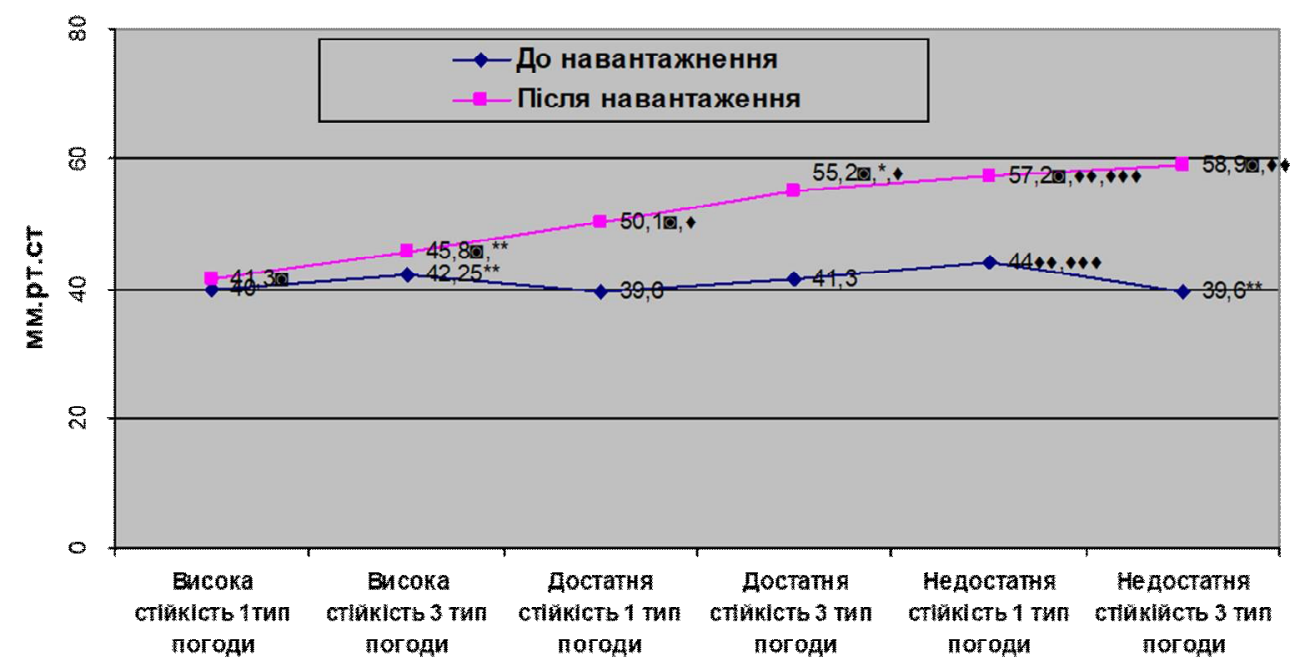

Рис. 1. Зміни ПТ після вестибулярного навантаження при різних типах погоди

Примітка: Ор $<0,01$ - вірогідність різниці показників до та після вестибулярного навантаження, p $<0,05^{*}$ - вірогідність різниці показників у стані спокою при I і III типах погоди; $\mathrm{p}<0,01$ **_- вірогідність різниці показників у стані спокою при I і ІІІ типах погоди; $\mathbf{p}<0,01 * * *$ - вірогідність різниці показників після вестибулярного навантаження при I і III типах погоди; $<<0,05^{* * * *}$ - вірогідність різниці показників після вестибулярного навантаження при I і III типах погоди; $>0,05$ - вірогідність різниці показників між особами 3 відмінною та достатньою ВC, $\diamond$ p $<0,05$ - вірогідність різниці показників між особами 3 відмінною та недостатньою ВС, $\diamond \bullet$ p $<0,05$ - вірогідність різниці показників між особами з достатньою та недостатньою ВС.

Досліджуючи вплив погоди, ми порівняли цей показник у всіх групах до та після обертальної проби при I і III типах, і встановили, що у них при III типі погоди він був достовірно вищим $(\mathrm{p}<0,01)$, ніж при I типі, як у стані спокою, так і після обертальної проби. 
До вестибулярного навантаження у групі 3 достатньою ВС ПТ не відрізнявся, а після - збільшився, як при I $(\mathrm{p}<0,01)$, так і при III типах погоди $(\mathrm{p}<0,01)$.

Порівнюючи значення ПТ до вестибулярного навантаження у групі з недостатньою ВC при I i III типах погоди, ми встановили, що при III типі він був нижчий, ніж при I $(\mathrm{p}<0,01)$. При порівнянні його між групами, ми встановили, що він був вищим після вестибулярного навантаження, як при I так і при III типі погоди, у групі з достатньою ВС, ніж у групі 3 високою ВС $(\mathrm{p}<0,05)$.

При порівнянні результатів визначення ПТ у осіб з високою ВС і групою 3 недостатньою ВС ми знайшли певні відмінності, а саме: у стані спокою ПТ був вищим у групі 3 недостатньою ВС, ніж у групі 3 високою ВС при I $(\mathrm{p}<0,05)$ і нижчим при III типі погоди $(\mathrm{p}<0,05)$; після вестибулярного навантаження
ПТ був вищим у групі з недостатньою ВC при I і III типах погоди, порівняно 3 групою 3 високою ВС $(\mathrm{p}<0,05)$.

При порівнянні значення ПТ у осіб з достатньою та недостатньою ВС ми спостерігали вищий ПТ у стані спокою у групі з недостатньою ВС, ніж у групі 3 достатньою ВС при I типі погоди та вищий ПТ після обертальної проби у групі з недостатньою ВС при I і III типах погоди, порівняно з групою із достатньою ВС $(\mathrm{p}<0,05)$.

При порівнянні ЗСПО (рис. 2) у групі з високою ВС у стані спокою при I і III типах погоди різниці ми не виявили.

Після обертальної проби ми виявили достовірне зниження ЗСПО при I і III типах погоди $(\mathrm{p}<0,01)$, однак при III типі ЗСПО був достовірно нижчим, ніж при І типі погоди $(\mathrm{p}<0,05)$.
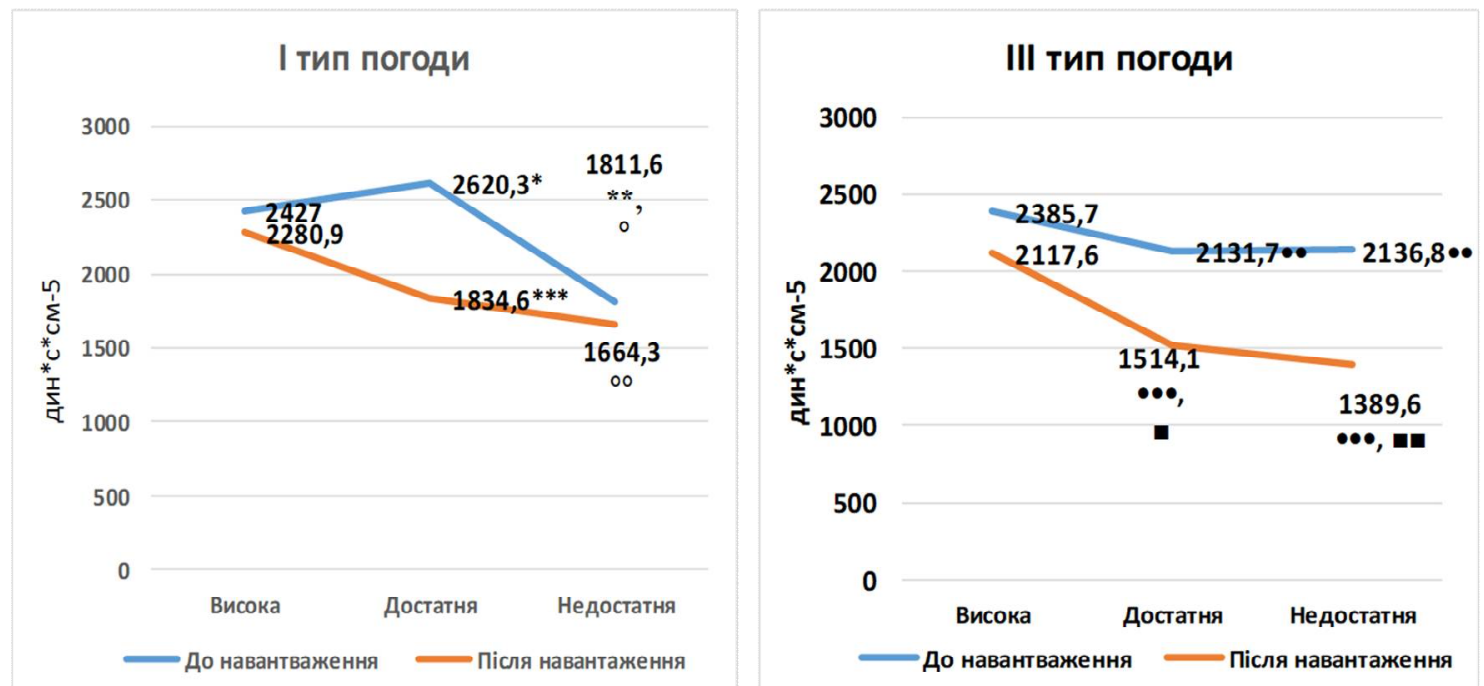

Рис. 2. Зміни ЗСПО при різних типах погоди (М) (дин $\left.{ }^{*}{ }^{*} c M^{-5}\right)$.

Примітка: ••p $<0,01$ - вірогідність різниці показників у стані спокою при I і III типах погоди; •••p $<0,01$ - вірогідність різниці показників після вестибулярного навантаження при I і III типах погоди; * р <0,01 - вірогідність різниці показників ЗСПО у стані спокою при І типі погоди між високою ВС та достатньою ВС; **p $<0,01$ - вірогідність різниці показників ЗСПО у стані спокою при І типі погоди між високою ВС та недостатньою ВС; ***p $<0,01$ - вірогідність різниці показників ЗСПО після вестибулярного навантаження при I типі погоди між високою ВС та достатньою ВС; ${ }^{\circ} \mathrm{p}<0,01$ - вірогідність різниці показників ЗСПО у стані спокою при I типі погоди між достатньою ВС та недостатньою ВС; ${ }^{\circ} \mathrm{p}<0,01$ - вірогідність різниці показників ЗСПО після вестибулярного навантаження при I типі погоди між з високою ВС та недостатньою ВC; $\mathbf{p}<0,01$ - вірогідність різниці показників ЗСПО після вестибулярного навантаження при III типі погоди між високою ВС та достатньою ВС; - $\mathrm{p}<0,01$ - вірогідність різниці показників ЗСПО після вестибулярного навантаження при III типі погоди між групою з високою ВС та групою з недостатньою ВС.

При порівнянні ЗСПО у групі із з достатньою ВС у стані спокою при I типі погоди був вищим, ніж при III типі погоди $(\mathrm{p}<0,01)$. Після обертальної проби ми виявили достовірне зниження ЗСПО при I і III типах погоди $(\mathrm{p}<0,01)$, і при порівнянні ЗСПО після обертальної проби при III типі погоди спостерігали зниження у порівнянні з I ( $<<0,01)$.

У групі із недостатньою ВС ЗСПО у стані спокою при III типі погоди був вищим, ніж при I типі погоди $(\mathrm{p}<0,01)$. Після вестибулярного навантаження зниження ЗСПО відбулось як при I, так і при III типі погоди $(\mathrm{p}<0,01)$, і при порівнянні цього показника після обертальної проби при III типі погоди спостерігали достовірне зниження порівняно з I (p<0,01).

Оцінювання зміни ЗСПО між групами з різною вестибулярною стійкістю при I і III типах погоди показало, що він у групі з високою ВС у стані спокою при I типі погоди вищий, ніж у групах із достатньою та недостатньою ВС ( $<0,01)$. При порівнянні показників після вестибулярного навантаження спостерігали зниження ЗСПО у групах із достатньою та недостатньою ВC, як при I, так і при III типах погоди, порівняно із групою з відмінною ВC $(\mathrm{p}<0,01)$. При порівнянні ЗСПО між групами із достатньою та недостат- 
ньою ВС відмінності ЗСПО знайшли у стані спокою при I типі погоди, а саме: він був вищим у групі з достатньою ВС, ніж у групі з недостатньою ВС $(\mathrm{p}<0,01)$.

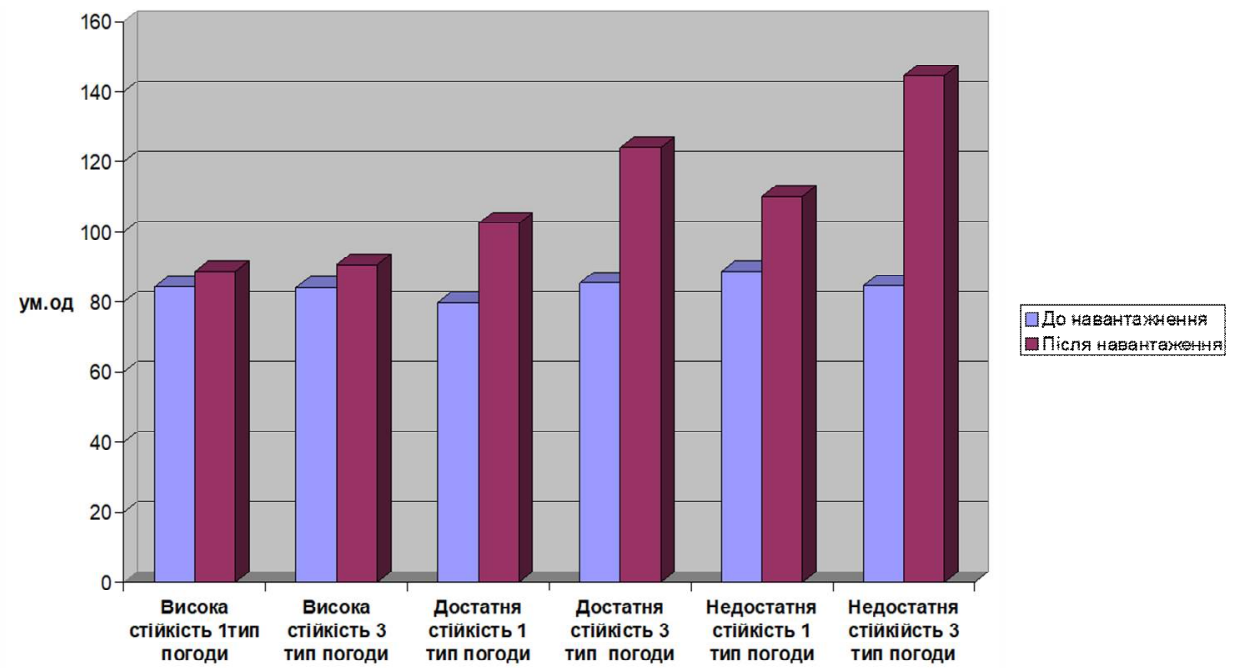

Рис. 3. Оцінка рівня обмінно-енергетичних процесів у міокарді за індексом Робінсона в осіб із різною вестибулярною стійкістю до та після вестибулярного навантаження при I та III типах погоди (М).

Аналізуючи індекс Робінсона (IP) (рис. 3) у групі з високою ВС до обертальної проби при I і III типах погоди, виявлено, що рівень енергетичних процесів (ОЕП) у міокарді, необхідний для забезпечення достатнього скорочення міокарда шлуночків у систолу, яке формує необхідний САТ при встановленій ЧСС, відповідає рівню вище середнього, а після середньому.

У групі із достатньою ВС до обертальної проби при I типі погоди рівень ОЕП відповідає рівню вище середнього, а після - середньому. При III типі погоди у стані спокою ОЕП був незмінним, а після вестибулярного навантаження відповідав низькому рівню ОЕП. У групі з недостатньою ВС у стані спокою ОЕП відповідав середньому рівню ОЕП, як при I так і при III типах погоди. Після вестибулярного навантаження рівень ОЕП відповідав низькому при III типі погоди.

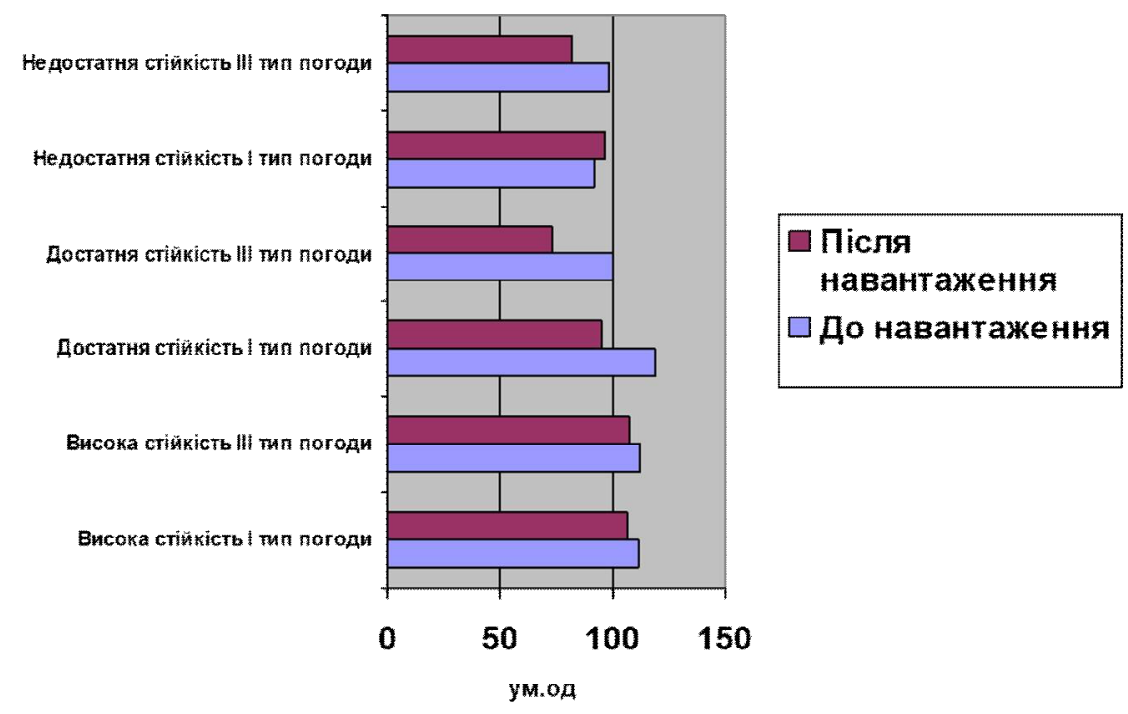

Рис. 4. Зміни рівня напруги механізмів регуляції діяльності серцево-судинної системи в осіб із різною вестибулярною стійкістю до та після вестибулярного навантаження при I і III типах погоди (М).

Тип саморегуляції кровообігу (рис. 4) в осіб із високою ВС у стані спокою при I і III типах погоди характеризується як судинний, а після обертальної проби змінився на серцево-судинний при I і III типах погоди, тобто регуляція системного кровообігу від- бувалась за рахунок симетричної взаємодії роботи серця та судинного тонусу. У групі з достатньою ВС при I типі погоди у стані спокою тип саморегуляції кровообігу характеризувався як судинний, а після обертальної проби змінився на серцево-судинний. 
При III типі погоди у групі з достатньою ВС до вестибулярного навантаження тип саморегуляції кровообігу характеризувався як серцево-судинний, а після - змінився на серцевий. Зміни типу саморегуляції кровообігу у групі із недостатньою ВС ми спостерігали при III типі погоди, а саме $з$ серцево-судинного на серцевий. При I типі погоди тип саморегуляції кровообігу відповідав серцево-судинному, як до, так і після обертальної проби.

Обговорення результатів. Вплив вестибулярного навантаження на діяльність серцево-судинної системи вивчали Л.К. Токаева, С.С. Павленкович, C.С. Паршина, Т.А. Беспалова [9] та ін., однак вони не враховували вплив погодних умов. Адже, у літературі наводяться дані досліджень функцій серцевосудинної системи людей, які проживають в екстремальних кліматичних зонах, де виявлено значне зниження рівня функціональних резервів, погіршення адаптаційних можливостей i, як наслідок, низьку резистентність організму до дії погодних чинників [3]. Наші дані підтверджують результати низки досліджень, а саме: автономна нервова система однією 3 перших реагує на зміну погодних чинників, що відповідно викликає зміну діяльності серцево-судинної системи і практично всіх органів і систем та організму в цілому [10]. Це вказує на те, що при III типі погоди в осіб із достатньою та недостатньою вестибулярною стійкістю погіршується витривалість вестибулярного навантаження за рахунок зниження рівня функціональних резервів серцево-судинної системи. У групі 3 недостатньою вестибулярною стійкістю обстежених було виявлено найбільш несприятливі зміни гемодинаміки після вестибулярного навантаження, на фоні зниженої витривалості $[11,12]$. За тривалого впливу вестибулярних подразників, такі юнаки характеризуються недосконалими механізмами адаптації. Оскільки вестибулярний аналізатор є найбільш чутливим до гіпоксії, а III тип погоди супроводжується гіпоксичним ефектом атмосфери, функціональний стан осіб зі зниженою стійкістю вестибулярного аналізатора погіршується внаслідок зниження функціональних і метаболічних резервів організму. Оскільки регулярні дозовані фізичні навантаження дозволяють знизити вразливість регуляторних систем організму до несприятливого впливу метеофакторів, вони можуть розглядатись як засіб метео-профілактики у осіб із достатньою та недостатньою стійкістю вестибулярного аналізатора $[1,10$, $13]$.

\section{Висновки:}

1. Проводячи оцінку зміни функціонування системи кровообігу при вестибулярному навантаженні при I і III типах погоди, встановили зниження вестибулярної стійкості при III типі погоди порівняно 3 I.

2. В умовах гіпоксичного впливу ефекту атмосфери виявили значні зрушення у функціонуванні автономної проекції вестибулярного аналізатора, що призводить до зниження адаптивних можливостей організму.

3. Рекомендовано проводити метеопрофілактику особам 3 достатньою та недостатньою вестибулярною стійкістю за допомогою фізичних тренувань на свіжому повітрі.

\section{References:}

1. Moiseienko O, Horchaniuk Yu, Horchaniuk V. Determination of the functional state of the vestibular analyzer volleyball players of 14-15 years under the influence of specially directed exercises. Slobozhans'kyi scientific and sport bulletin, 2015; 2, 46:133-137. dx.doi.org/10.15391/snsv.2015-2.026. [in Ukrainian].

2. Nerianova Yu, Kuzmenko L. Experience of using hirudotherapy in the complex treatment of vertigo in patients with dyscirculatory encephalopathy. Zaporozhye Medical Journal, 2014; 2:48-50.

3. Australian Institute of Health and Welfare 2018. Australia's health 2018. Australia's health series no. 16. Cat. No. AUS 221. AIHW, Canberra: 166-178.

4. Ihoshyna AV, Nikolenko VIu, Tyshchenko HV, Nikolenko OV. The main vegetative-vestibular disorder in toxic toxicosis enlarged the state of the living room with carbon monoxide and methane in coal mines in coal mines. International Neurology Journal, 2015; 5(75):143148 .

5. Trinus KF. Dizziness correlation with hypertension. International Neurology Journal, 2015; 4(74):13-19.

6. Musalymova RS, Mukhamedova AA. Evaluation of the functional state of the vestibular analyzer students of a pedagogical university. Natural and mathematical sciences in the modern world: XIX international scientificpractical conf. Novosibirsk: SIBAK - 2014; 6(18):130137. [in Russian].

7. Honcharuk ND. To the method of determining the types of central hemodynamics. Scientific works. Technological safety, 2014; 238(226):40-44. [in Ukrainian].

8. Glantz, Stanton A. Primer of biostatistics. New York : McGraw-Hill Medical. 2012.

9. Tokaeva LK, Pavlenkovych SS, Parshyna SS, Bespalova TA. Features of adaptive reactions of the cardiovascular system of student-athletes with different vestibular resistance and vegetative regulation. Scientific Review. Biological sciences, 2014; 6:160-161. [in Russian]. 10. Opanasyuk FG, Denzelyuk DO, Kurillo TV, Skory OS. Prevention of arterial hypertension by means of motor activity: a teaching method. manual. - Zhytomyr: Published by O. O. Evenok, 2018. P.300.

11. Hallgren, E.et al. Dysfunctional vestibular system causes a blood pressure drop in astronauts returning from space, 2015; Sci. Rep.5, 17627; doi: 10.1038/srep17627. 12. Yates BJ, Bolton PS, Macefield VG. Vestibulosympathetic responses. Compr. Physiol., 2014; 4:851887.

13. Zolochevskyi VV, Popov FI. Means of improvement of vestibular stability and spatial orientation of the flight composition. Physical Culture, Sport and Health: Materials of the XVII International Scientific and Practical Conference. Kharkiv: KDAFK; 2017. P.9-11[in Ukrainian]. 
УДК 612.1-06:616.281:616.15

\section{ВЛИЯНИЕ ВЕСТИБУЛЯРНОЙ НАГРУЗКИ НА СИСТЕМУ КРОВООБРАЩЕНИЯ ПРИ РАЗНЫХ ТИПАХ ПОГОДЫ}

\author{
С.Н. Вадзюк, Р.М. Шмата, Л.Б. Лозына
}

Тернопольский национальный медицинский университет имени И.Я. Горбачевского МОЗ Украины, кафедра физиологии с основами биоэтики и биобезопасности, г. Тернополь, Украина,

ORCID ID: 0000-0001-9105-8205,

e-mail:vadzyuk@tdmu.edu.ua,

ORCID ID: 0000-0003-0773-4717,

e-mail:roman@tdmu.edu.ua,

ORCID ID: 0000-0001-6129-0097,

e-mail:lozyna@tdmu.edu.ua

Резюме. Исследование функциональной активности вестибулярного анализатора имеет важное значение, поскольку он не только контролирует положение тела в пространстве, обеспечивает его равновесие, но и принимает участие в регуляции функционирования других систем организма.

Цель исследования. Оценить влияние вестибулярной нагрузки на функциональное состояние системы кровообращения при различных типах погоды для определения в будущем показаний к метеопрофилактики.

Материалы и методы. Определяли величину артериального давления и частоту сердечных сокращений до и после вестибулярной нагрузки, на основе которых оценивали вестибулярную устойчивость при I и III типах погоды.

Результаты исследования и их обсуждение. При I типе погоды у лиц с отличной вестибулярной устойчивостью мы наблюдали повышение показателей систолического и диастолического АД и ЧСС, что при оценке вестибулярной устойчивости по методике Н.Н. Лозанова и И.П. Байченка равно в среднем 4,8 балла. При III типе погоды в тех лиц, которые не отмечали проявлений вестибулярной дисфункции, мы наблюдали тенденцию к снижению вестибулярной устойчивости. У лиц с достаточной вестибулярной устойчивостью и недостаточной вестибулярной устойчивостью, при I типе погоды вестибулярная устойчивость равна 2,8 балла. При III типе погоды количество лиц $\mathrm{c}$ недостаточной вестибулярной устойчивостью значительно увеличилось, а именно: в 57\% лиц, у кого при I типе погоды показатель вестибулярной устойчивости равен уровню «достаточная устойчивость», при III типе он снизился до уровня «недостаточная вестибулярная устойчивость».

Выводы. При оценке ответа системы кровообращения на вестибулярные нагрузки при I и III типах погоды установили снижение вестибулярной устойчивости при III типе погоды в сравнении с I.

Ключевые слова: вестибулярная устойчивость, тип погоды, артериальное давление, частота сердечных сокращений.
UDC 612.1-06:616.281:616.15

\section{INFLUENCE OF VESTIBULAR LOADING ON THE CIRCULATORY SYSTEM IN VARIOUS TYPES OF WEATHER}

\author{
S.N. Vadzyuk, R.M. Shmata, L.B. Lozina
}

I. Horbachevsky Ternopil National Medical University, department of physiology with the basis of bioethics and biosafety, Ternopil, Ukraine,

ORCID ID: 0000-0001-9105-8205,

e-mail:vadzyuk@tdmu.edu.ua,

ORCID ID: 0000-0003-0773-4717,

e-mail:roman@tdmu.edu.ua,

ORCID ID: 0000-0001-6129-0097,

e-mail:lozyna@tdmu.edu.ua

Abstract. Investigations of the functional activity of the vestibular analyzer are important because it does not only controls the position of the body in space and provides its balance, but also takes part in the regulation of the functioning of other systems of the body. However, it is known that the weather, affecting humans, causes a variety of reactions of the body through the integral nature and its multifactorial action. The scientific literature presents data on reactions to the effects of weather factors from different systems of the body.

The aim of the study. Evaluate the effect of vestibular loading on the functional state of the circulatory system in different types of weather to determine future meteorological prophylaxis.

Materials and methods. We evaluated vestibular stability by Lozanova and Baichenko method, performing rotational tests on the chair Barani in the I and III types of weather. Blood pressure and heart rate were determined before and after vestibular loading. Vestibular stability was evaluated in points on the following scale: above 4.5 points - high stability of the vestibular analyzer, from 3.0 to 4.5 - sufficient, below 3.0 points - insufficient.

The parameters obtained from an objective examination of the cardiovascular system were used to calculate the pulse pressure that reflects the kinetic energy of the bloodstream; general vascular peripheral resistance; the level of metabolic and energy processes in the myocardium, according to the Robinson index; changes in the voltage level of the mechanisms of regulation of cardiovascular system activity.

Research results and their discussion. Under the conditions of the first type of weather, in individuals with high vestibular stability, we observed changes in systolic and diastolic blood pressure and heart rate, which were based on Lozanov's and Baychenko's method, which was 4.8 points, when evaluating vestibular stability. In the case of the third type of weather, in individuals who did not observe vestibular dysfunction, we observed a tendency to decrease vestibular stability. For students with sufficient and insufficient resistance of the vestibular analyzer, in the case of the first type of weather, vestibular stability was 2.8 points, which was accompanied by a greater change in blood pressure and heart rate, than in students with high vestibular analyzer stability. Under conditions of the third type of weather compared with the 
first, changes in the circulatory system after rotation test showed significant fluctuations of systolic, diastolic and high blood pressure. This indicates a decrease in vestibular stability under the conditions of the third type of weather. In the case of the third type of weather, the number of people with insufficient vestibular stability increased, namely $57 \%$ of people for the first type of weather, the index of vestibular stability was equal to the level of "sufficient stability", but under the conditions of the third type went down to the level of "insufficient vestibular stability".

Our results indicate that in the third type of weather among people with sufficient and insufficient vestibular stability, the endurance of the vestibular load decreases due to the decrease in the level of functional reserves of the cardiovascular system. With prolonged exposure to vestibular stimuli, such individuals are characterized by imperfect adaptation mechanisms.

Conclusions. By assessing the response of the circulatory system to vestibular loading in types I and III of weather, we found a decrease in vestibular stability in type III of weather compared with type I.

Keywords: vestibular stability, type of weather, arterial pressure, frequency of cardiac contractions.

Стаття надійшла в редакцію 31.10.2019 р. 